\title{
ASSOCIATIONS OF KNOWLEDGE AND ATTITUDE WITH MENOPAUSAL READINESS AMONG WOMEN IN SLEMAN, YOGYAKARTA
}

\author{
Endang Puji Ati, Murni, Almira Gitta Novika
}

Faculty of Health Sciences, Universitas Respati Yogyakarta

\begin{abstract}
Background: Menopause is the process through which a woman ceases to be fertile or menstruate. It is a normal part of life and is not considered a disease or a condition. Most women will experience menopausal symptoms. Some of these can be quite severe and have a significant impact on women everyday activities. This study aimed to investigate the associations of knowledge and attitude with menopausal readiness among women in Sleman, Yogyakarta.

Subjects and Method: A cross-sectional study was conducted in Sleman, Yogyakarta. A total of 83 women aged 40-49 years was selected for this study by purposive sampling. The dependent variable was menopausal readiness. The independent variables were knowledge and attitude. The data were collected using questionnaire. The association between variables was measured by correlation coefficient (r).

Results: $57.8 \%$ of the premenopausal women sufficient knowledge. $53 \%$ of them had positive attitude. $56.6 \%$ of the premenopausal women were not ready to face menopause. Knowledge was positively associated with menopausal readiness $(\mathrm{r}=0.27 ; \mathrm{p}=$ 0.017), and it was statistically significant. Attitude showed weak association with menopausal readiness $(\mathrm{r}=0.05 ; \mathrm{p}=0.686)$.

Conclusion: Knowledge premenopausal syndrome is associated with menopausal readiness among women in Sleman, Yogyakarta.
\end{abstract}

Keywords: knowledge, attitude, readiness, premenopause

Correspondence:

Endang Puji Ati. Faculty of Health Sciences, Universitas Respati Yogyakarta, Yogyakarta, Indonesia. Email: Pujiapuji17@gmail.com. Mobile: 085337607271.

The $6^{\text {th }}$ International Conference on Public Health Best Western Premier Hotel, Solo, Indonesia, October 23-24, 2019 | 174 